\title{
Peran Direktorat Jenderal Imigrasi Sebagai Fasilitator Pembangunan Masyarakat Dalam Skema Kerjasama IA-CEPA
}

\author{
Anita Herlina ${ }^{1}$ \\ ${ }^{1}$ Politeknik Imigrasi, Badan Pengembangan Sumber Daya Manusia Kementerian \\ Hukum dan Hak Asasi Manusia RI, herlina.anita@gmail.com
}

\begin{abstract}
Abstrak
Indonesia-Australia Comprehensive Economic Partnership Agreement (IA-CEPA) yang disepakati pada tahun 2019 perlu didukung dengan kebijakan di berbagai sektor agar dapat menjadi positive-sum game bagi kedua belah pihak. Penelitian ini bertujuan untuk menganalisis peran Direktorat Jenderal Imigrasi dalam kerangka Kerjasama IA-CEPA. Penelitian ini menggunakan metode kualitatif deskriptif. Teknik pengumpulan data dilakukan dengan metode data sekunder. Hasil penelitian menunjukkan bahwa Direktorat Jenderal Imigrasi telah memiliki kebijakan berupa fasilitas kemudahan keimigrasian yang dapat digunakan dalam skema IA-CEPA. Kebijakan tersebut yaitu Kartu Perjalanan Pebisnis APEC (KPP APEC) dan Working Holiday Visa (WHV). Kedua kebijakan tersebut telah lama digunakan digunakan sebelum IA-CEPA disepakati, namun dapat tetap digunakan dalam kerangka kerjasama kemitraan tersebut karena sifatnya yang memberikan kemudahan bagi kedua warga negara dalam hal perlintasan. Dengan demikian, Direktorat Jenderal Imigrasi telah menjalankan fungsinya sebagai fasilitator pembangunan masyarakat dalam hal memberikan fasilitas keimigrasian bagi perpindahan manusia dalam skema IA-CEPA.
\end{abstract}

Kata kunci : Direktorat Jenderal Imigrasi, IA-CEPA, KPP APEC, Working Holiday Visa

\begin{abstract}
The Indonesia-Australia Comprehensive Economic Partnership Agreement (IA-CEPA) which was approved in 2019 needs to be supported by policies in various sectors in order to create a positive-sum game for both parties. This study aims to analyze the role of the Directorate General of Immigration in the framework of IA-CEPA Cooperation. This research uses a descriptive qualitative method. The data collection method uses a secondary data method. The result shows that the Directorate General of Immigration already has policies that can be used in the IA-CEPA scheme. Those policies include the APEC Businessman Travel Card (KPP APEC) and the Working Holiday Visa (WHV). Both policies have long been used before the IA-CEPA was approved, but can still be used within the framework of this partnership cooperation since it gives facilities for border crossing. Thus, The Directorate General of Immigration has carried out its function as a facilitator of society development in terms of providing immigration facilities for human movement under the IA-CEPA scheme.
\end{abstract}

Keywords: Directorate General of Immigration, IA-CEPA,KPP APEC,Working Holiday Visa 


\section{Pendahuluan}

Kerjasama antar negara merupakan suatu keniscayaan dalam tatanan dunia global. Di dalam studi hubungan internasional, kerjasama internasional dapat dipahami dari teori liberalisme. Tidak seperti teori realisme yang fokus kepada kekuasaan (power) dan politik (politics) sebagai motivasi utama aktor negara (state actor) berperilaku, liberalisme lebih menekankan pada pertumbuhan ekonomi, integrasi regional dan kerjasama antar negara, sehingga perang tidak lagi menjadi pilihan (Tickner, 2001). Liberalisme dalam studi hubungan internasional mendapatkan pengaruh kuat dari pemikiran Adam Smith dan David Ricardo mengenai pasar bebas (free market). Kapitalisme dan demokrasi merupakan bagian penting dari liberalisme yang melahirkan ide mengenai perdagangan bebas (free trade). Saling ketergantungan antarnegara merupakan implikasi dari perdagangan bebas, yang pada akhirnya memberikan keuntungan bagi semua pihak (positivesum game). Dengan demikian, dasar pemikiran liberalisme berlawanan dengan realisme yang meyakini bahwa hasil interaksi antar negara dalam sistem internasional adalah hanya satu pihak yang memperoleh keuntungan, sementara yang lain tidak atau disebut dengan zero-sum game (Bakry, 2017).

Salah satu bentuk kerjasama Indonesia dengan negara lain yang baru-baru ini disepakati adalah The Indonesia-Australia Comprehensive Economic Partnership Agreement (IA-CEPA). Kerjasama bilateral IA-CEPA adalah tonggak bersejarah dalam hubungan bilateral kedua negara di bidang ekonomi, mengingat sebelumnya belum ada perjanjian kerjasama ekonomi dalam bentuk partnership antara kedua negara. Meskipun perjanjian tentang investasi dan perdagangan antara Indonesia-Australia telah diatur di dalam skema ASEAN-Australia-New Zealand Free Trade Agreement/AANZTA (Andriani \& Andre, 2017), namun perjanjian tersebut merupakan perjanjian multilateral, tidak spesifik hanya antara kedua negara.

Indonesia-Australia meyakini bahwa kerjasama IA-CEPA dapat menjadi positive-sum game bagi kedua belah pihak. Lebih daripada itu, pemerintah Australia menyatakan bahwa IA-CEPA tidak hanya memperkuat kerjasama ekonomi kedua negara, namun juga mempererat hubungan dalam bidang politik, 
keamanan, pembangunan, maritim, pendidikan dan people to-people antara kedua negara (Minister for Trade, Tourism and Investment, 2020). Indonesia juga menyatakan bahwa perjanjian tersebut akan memberikan kesempatan bagi kedua negara untuk menciptakan Economic Powerhouse. Indonesia dan Australia dapat saling menggunakan keunggulan masing-masing guna meningkatkan keterlibatan kedua negara pada rantai nilai global (global value chain). Economic power house adalah kerjasama perdagangan yang tidak hanya berorientasi di pasar masingmasing negara, namun juga berorientasi pada pasar negara ketiga atau pasar dunia. Sedangkan global value chain adalah mata rantai bisnis atau produk yang menghubungkan suatu produk dari awal hingga akhir yaitu mulai dari produsen, pengolah, pemasok hingga konsumen akhir dalam skala internasional.

Indonesia berharap, IA-CEPA dapat mendorong peningkatan ekspor berbagai komoditas dalam negeri ke Australia serta meningkatkan arus investasi antara kedua negara (Konsulat Jenderal RI Melbourne-Victoria , 2020). Di akhir tahun 2017, menurut World Trade Organisation (WTO), indeks kontribusi Indonesia di dalam global value chain masih lebih rendah dibandingkan dengan negara Malaysia dan Thailand. Indeks kontribusi Indonesia adalah sebesar 43,5, angka tersebut di bawah rata-rata kontribusi agregat negara berkembang sebesar 48,5. Sementara kontribusi Malaysia sangat tinggi yaitu 60,8, dan Thailand sebesar 54,3 (Riyandi, 2017).

Penelitian ini akan menjelaskan bahwa Direktorat Jenderal Imigrasi telah memiliki kebijakan kemudahan fasilitas keimigrasian yang dapat digunakan dalam skema IA-CEPA yaitu KPP APEC dan WHV. Beberapa isu penting yang dibahas di dalam penilitian ini adalah: pertama, bahwa IA-CEPA merupakan kerjasama ekonomi komprehensif yang tidak hanya mengatur aspek perdagangan barang dan jasa, namun juga aspek investasi dan hubungan people to people. Kedua, bahwa IA-CEPA tidak hanya memiliki arti penting dari perspektif ekonomi, namun juga dari perspektif hubungan diplomatik kedua negara. Ketiga, fasilitas keimigrasian Kartu Pebisnis APEC (KPP APEC) dan Working Holiday Visa (WHV) merupakan fasilitas keimigraisan yang diberikan dalam memfasilitasi perpindahan manusia dalam kerangka kerjasama IA-CEPA. Terakhir, Direktorat Jenderal Imigrasi telah 
menjalankan fungsinya sebagai fasilitator pembangunan masyarakat dalam kerjasama IA-CEPA dengan memberikan kebijakan KPP APEC dan WHV.

Berdasarkan latar belakang tersebut, penelitian ini bertujuan untuk mengindentifikasi bagaimana peran Direktorat Jenderal Imigrasi sebagai fasilitator pembangunan masyarakat dalam kerangka Kerjasama IA-CEPA.

\section{Metode}

Metode yang digunakan di dalam penelitian ini adalah kualitatif dengan pendekatan kualitatif deskriptif. Pengumpulan data dilakukan secara gabungan, data dianalisis dengan sifat induktif/kualitatif yang hasilnya menekankan makna generalisasi (Anggito dan Setiawan, 2018). Penelitian ini menganalisis kebijakan Direktorat Jenderal Imigrasi yang dapat digunakan dalam kerangka Kerjasama IACEPA yaitu KPP APEC dan WHV. Kedua kebijakan keimigrasian tersebut merupakan kebijakan yang dihasilkan dari kerjasama Indonesia-Australia dalam aspek lalu lintas manusia keluar masuk wilayah suatu negara sebelum diberlakukannya IA-CEPA. Teknik pengumpulan data dilakukan dengan metode data sekunder (secondary data), yaitu dengan mengumpulkan bahan berupa peraturan perundangan, bahan pustaka (buku, karya ilmiah, artikel), website dan sumber data sekunder lainnya yang terkait dengan topik penelitian ini.

\section{Hasil dan Pembahasan}

\section{Kerjasama IA-CEPA Mengatur Aspek Perdagangan, Investasi dan People To People}

IA-CEPA mempunyai sejarah panjang sebelum akhirnya final disepakati oleh kedua negara pada tahun 2019. Inisiatif mengenai IA-CEPA pertama kali dimulai pada tahun 2007, kemudian negosiasi formal dimulai pada tahun 2010 . Salah satu hambatan dalam merealisasikan IA-CEPA adalah terdapat beberapa hal spesifik terkait kebijakan perdagangan bilateral yang harus dirumuskan karena tidak diatur oleh World Trade Organisation (WTO) sebagai lembaga yang mengatur tata cara perdagangan internasional. WTO hanya mengatur hal-hal pokok saja terkait kebijakan perdagangan seperti tarif, subsidi dan pembatasan kuantitatif. 
Sedangkan beberapa aspek dari kebijakan perdagangan tidak diatur di dalam WTO seperti aturan investasi, perdagangan jasa, intelektual property, keuangan, pemerintahan, pertanian dan perpindahan manusia (Wilson, 2016). Hingga akhirnya kedua negara sepakat untuk bekerjasama pada tahun 2019. Parlemen Australia meratifikasi perjanjian IA-CEPA pada tanggal 26 November 2019. Sementara itu Indonesia mengesahkan perjanjian ini pada tanggal 6 Januari 2020 (Konsulat Jenderal RI Melbourne-Victoria, 2020). Saat ini pemerintah Indonesia sedang menyusun Rancangan Undang-Undang (RUU) IA-CEPA yang bertujuan untuk meningkatkan akses terhadap barang dan jasa di segala sektor seperti peningkatan arus tenaga kerja serta fasilitas arus barang dan kepabeanan. Selain itu, RUU tersebut diharapkan juga akan meningkatkan akses terhadap penanaman modal, pengembangan sumber daya manusia Indonesia, economic powerhouse, dan program kerjasama ekonomi lainnya. (Maharani, 2020).

Terdapat beberapa alasan penting mengapa kedua negara sepakat untuk saling bekerjasama secara partnership (kemitraan). Dari perspektif Australia, Indonesia merupakan ekonomi terbesar di Asia Tenggara dan ekonomi ke-16 terbesar di dunia setelah Spanyol dan Meksiko. Kedua, Indonesia berpotensi untuk menjadi ekonomi terbesar ke-4 di dunia pada tahun 2050 berdasarkan angka Gross Domestic Product (GDP). Hal ini didasarkan pada fakta bawa pertumbuhan ekonomi Indonesia sebesar lima persen pada tahun terakhir, meskipun saat ini pertumbuhan ekonomi Indonesia minus sebagai dampak pandemik Covid-19. Ketiga, Indonesia merupakan negara dengan populasi penduduk usia produktif, dimana pada tahun 2017 sekitar 44 persen total populasi berusia dibawah 25 tahun. Terakhir, angka kemiskinan Indonesia yang terus menurun, selama kurun waktu 10 tahun (2007-2017) turun dari 6 persen menjadi 10,6 persen (Department of Foreign Affairs and Trade, 2020). Sementara itu, dari perspektif Indonesia, Australia juga merupakan pasar yang potensial untuk investasi dan eskpor. Indonesia berharap dapat menjadi 10 besar negara tujuan penanaman modal Australia. Saat ini, Indonesia merupakan urutan ke-13 sebagai negara tujuan investasi Australia setelah Malaysia dan Vietnam (Workman, 2020). 
IA-CEPA merupakan kerjasama partnership yang komprehensif karena ruang lingkupnya yang sangat luas. Ruang lingkup IA-CEPA tidak hanya di bidang perdagangan barang dan jasa, namun juga investasi, dan hubungan people to people. Di dalam bidang perdagangan, IA-CEPA mengurangi hambatan non-tariff dalam perdagangan dan penyederhanaan dokumen. Indonesia akan memotong 94 persen bea impor bagi produk impor asal Australia secara bertahap. Australia juga memberikan kebijakan yang sama terhadap produk asal Indonesia dengan menghapus bea masuk sebanyak 100 persen. Terdapat 6.474 pos tarif bea masuk impor nol persen bagi produk asal Indonesia yang akan diberikan oleh Australia. Adanya kebijakan nol persen tersebut diprediksi dapat meningkatkan ekspor produk otomotif seperti hybrid dan mobil listrik. Lebih lanjut, diperkirakan akan terjadi peningkatan ekspor produk seperti kayu, produk tekstil, perabot rumah, ban, alat komunikasi, perangkat elektronik, mesin dan obat-obatan (CNN Indonesia, 2020).

Dalam bidang investasi, IA-CEPA mencakup penanaman modal melalui program kerjasama kedua negara yang didanai bersama. Program tersebut akan mendukung bantuan teknis dan peningkatan kapasitas di banyak sektor perdagangan guna memperkuat dan menstimulasi hubungan dagang dan investasi dua arah (Kedutaan Besar Australia, 2020). Indonesia berharap mendapatkan investasi dari Australia dalam berbagai sektor antara lain energi, pariwisata, infrastruktur, e-commerce dan pengolahan makanan (Konsulat Jenderal RI Melbourne-Victoria, 2020). Lebih lanjut, diharapkan Australia dapat berinvestasi lebih banyak di sektor vocational education and training (VET) dan pendidikan tinggi. Hal ini sejalan dengan visi Presiden Joko Widodo untuk meningkatkan sumber daya manusia melalui pengembangan pendidikan vokasi serta sektor pendidikan tinggi. Indonesia berkomitmen untuk membuka lebih banyak akses investasi Australia di sektor Pendidikan (Konsulat Jenderal RI Melbourne-Victoria, 2020). Sebagai implikasi dari IA-CEPA, salah satu universitas terbesar di Australia, Monash University (Melbourne) akan membuka kampus di Indonesia (Kumparan.com, 2020). Western Australia University (Perth) juga sedang mempertimbangkan rencana untuk berinvestasi di Indonesia (Sebayang, 2020). 
Ruang lingkup IA-CEPA juga berpotensi meningkatkan hubungan people to-people, dalam hal pertukaran tenaga profesional. Tenaga profesional tertentu seperti tenaga ahli di bidang industri keuangan, asuransi, pertambangan dan teknologi informasi dan komunikasi bisa mendapatkan pengalaman kerja selama enam bulan di kedua negara (Minister for Trade, Tourism and Investment, 2020). IA-CEPA juga memberikan keuntungan dalam hal peningkatan kualitas sumber daya manusia melalui berbagai program, misalnya program magang pada sektor industri dan pendidikan kejuruan (CNN Indonesia, 2020).

Mengingat usia IA-CEPA yang baru diratifikasi pada awal Januari 2020, maka dampak positif IA-CEPA bagi perdagangan antara kedua negara belum bisa dilihat. Namun, skema kerjasama ini diprediksi akan memberikan keuntungan bagi kedua negara. IA-CEPA diperkirakan akan berdampak pada Gross National Product (GNP) kedua negara. Pada tahun 2030, diperkirakan GNP Australia akan meningkat lebih dari $0,02 \%$ lebih, sementara GNP Indonesia akan mengalami kenaikan lebih dari 0,23\% (Andriani \& Andre, 2017). Kalkulasi keuntungan yang akan diperoleh didasarkan pada fakta bahwa Indonesia dan Australia adalah mitra dagang yang potensial. Pada tahun 2018-2019, total perdagangan barang dan jasa dari Indonesia saja sebesar 17.8 milyar dollar Australia (Australian government Department of Foreign Affairs and Trade, 2020). Ekspor utama Australia ke Indonesia meliputi gandum, gula, gula tetes, madu, hewan ternak hidup, makanan laut (seafood), alumunium, minyak mentah dan kapas. Sementara itu, Indonesia mengeskpor bahan dasar dan produk manufaktur ke Australia seperti produk coklat, kayu, kertas dan papan kertas, dan ban karet (Andriani \& Andre, 2017). Berdasarkan data dari Department of Foreign Affairs and Trade pemerintah Australia (2020), pada tahun 2018, ekspor produk agrikultur dari Australia ke Indonesia seperti gandum, hewan ternak hidup diperkirakan sebesar 2,8 miliar dolar Australia. 


\section{Implikasi IA-CEPA Sebagai Media Untuk Mewujudkan 'Strategic Trust'}

\section{Antara Indonesia-Australia}

Selain dari perspektif ekonomi, IA-CEPA juga memiliki nilai penting bagi hubungan diplomatik kedua negara. Hal ini dikarenakan hubungan IndonesiaAustralia yang penuh kompleksitas. Menurut Sulistiyanto (2010), meskipun kedua negara dekat secara geografis, namun mereka merasa bahwa mereka tidak mengenal satu sama lain dengan baik, yang bahkan menimbulkan kesalahpahaman diantara kedua negara. Namun demikian, Indonesia-Australia perlu memiliki hubungan yang baik karena Indonesia adalah tetangga terdekat Australia. Oleh karenanya, kedua negara harus bekerjasama, suka atau tidak. Hubungan antara Indonesia dan Australia digambarkan oleh Ball dan Wilson (1991) sebagai 'strange neighbours', sebuah istilah untuk menggambarkan kompleksitas dan kesulitan yang dihadapi oleh kedua negara dalam mempertahankan dan memelihara hubungan bilateral. Hubungan kedua negara seringkali diwarnai dengan konflik seperti dalam kasus Tampa Affair. Tampa Affair adalah peristiwa penyelamatan 433 pencari suaka oleh kapal Norwegia MV Tampa karena kapal pencari suaka tersebut tenggelam dalam perjalanannya dari Indonesia ke Australia, namun MV Tampa ditolak masuk oleh Australia karena kebijakan Operation Relex pada tahun 2001. Konflik lainnya yang juga menimbulkan ketegangan antara kedua negara yaitu skandal penyadapan oleh Australia terhadap percakapan telepon Presiden Susilo Bambang Yudhyono pada tahun 2009.

Menurut Troath (2020), hubungan Indonesia Australia seperti roller coaster, dilanda krisis yang terkadang besar dan kecil, kedua pihak saling berjuang untuk mempertahankan hubungan yang imbang. Saat ini, hubungan antara Indonesia-Australia juga semakin tegang dikarenakan penarikan sementara Duta Besar Australia untuk Indonesia, Gary Quinlan, pada tanggal 9 April 2020 sebagai bentuk pencegahan penularan Covid-19. Kementerian Luar Negeri Indonesia menyatakan kekecewaannya terhadap sikap yang diambil oleh Canberra karena hal ini dimaknai sebagai ketidakpercayaan Australia terhadap kesiapan Indonesia menangani Covid-19. Lebih lanjut, Indonesia menganggap Australia tidak 
melakukan apapun untuk meluruskan berita negatif di media perihal penarikan Gary Quinlan (Souisa, 2020).

Kesepakatan Kerjasama IA-CEPA merupakan momentum yang sangat penting bagi hubungan diplomatik kedua negara. Dengan disepakatinya kerjasama IA-CEPA diharapkan hubungan kedua negara dapat lebih kondusif dan lebih sedikit konflik. Menurut Menteri Luar Negeri Indonesia, Retno Marsudi, IndonesiaAustralia memasuki babak baru dari apa yang disebut oleh sebagai "strategic trust". Menurutnya, hubungan Indonesia-Australia yang lebih penuh kepercayaan akan menjadi manfaat yang penting bagi wilayah Indo Pasifik (Troath, 2020).

\section{Kartu Pebisnis APEC dan Working Holiday Visa sebagai Fasilitas Keimigrasian dalam Kerangka Kerjasama IA-CEPA}

Implikasi IA-CEPA dalam bidang arus lalu lintas manusia dalam kerangka IA-CEPA dapat dibedakan menjadi empat yaitu untuk tujuan bisnis, pertukaran tenaga ahli, pelatihan vokasi dan berlibur sambil bekerja. Dengan demikian penting bagi Direktorat Jenderal Imigrasi untuk berperan secara aktif memberikan fasilitas keimigrasian bagi warga negara kedua belah pihak dalam rangka IA-CEPA. Saat ini belum terdapat skema khusus kebijakan keimigrasian yang memfasilitasi pergerakan manusia dalam kerangka IA-CEPA. Namun, sebenarnya imigrasi telah menjalankan beberapa kebijakan yang dapat digunakan untuk skema kerjasama IACEPA. Kebijakan tersebut memang tidak secara langsung ditujukan bagi kerangka kerjasama IA-CEPA, namun kebijakan tersebut dapat terus digunakan selama belum ada kebijakan yang khusus mengaturnya. Fasilitas kemudahan keimigrasian yang telah ada di Direktorat Jenderal Imigrasi saat ini adalah sebagai berikut:

\section{a. Kartu Perjalanan Pebisnis Asia Pacific Economic Cooperation}

Sejak tahun 2003, Direktorat Jenderal Imigrasi menjadi otoritas yang berwenang untuk mengeluarkan Kartu Perjalanan Pebisnis Asia Pacific Economic Cooperation (KPP APEC). Fasilitas ini diberikan khusus bagi pebisnis negara anggota Asia Pacific Economic Cooperation (APEC) berdasarkan asas resiprokal. Meskipun KPP APEC khusus dibuat dalam rangka Kerjasama APEC, namun dikarenakan Indonesia dan Australia adalah negara anggota APEC, maka pemberian KPP APEC dapat digunakan sebagai bentuk fasilitas keimigrasian dalam 
kerangka Kerjasama IA-CEPA. Hal ini sesuai dengan ketentuan di dalam treaty IACEPA, Indonesia-Australia Comprehensive Economic Agreement, Chapter 12 Movement of Natural Persons, article 12.5 sebagai berikut:

The Parties affirm their APEC commitments to each other to enhance the mobility of natural persons and their support for efforts to enhance the APEC Business Travel Card programme.

(Para pihak menegaskan komitmen APEC mereka satu sama lain untuk meningkatkan pergerakan orang perorangan dan dukungan mereka untuk upaya meningkatkan program Kartu Perjalanan Bisnis APEC).

Berdasarkan Peraturan Menteri Hukum dan HAM Nomor 26 Tahun 2016 tentang Kartu Perjalanan Pebisnis Asia Pacific Economic Cooperation, pasal 1 angka 1:

KPP APEC adalah kartu elektronik yang diterbitkan oleh pejabat yang berwenang dari negara anggota APEC berdasarkan perjanjian dan memuat identitas pemegangnya untuk melakukan perjalanan dan tinggal di negara yang telah memberikan persetujuan.

KPP APEC berlaku untuk jangka waktu lima tahun dan dapat digunakan di negara-negara anggota $A P E C$ sebanyak 19 negara. Negara-negara tersebut yaitu Australia, Brunei Darusalam, Chili, Cina, Hongkong, Indonesia, Jepang, Korea Selatan, Malaysia, Meksiko, Selandia Baru, Papua Nugini, Peru, Philipina, Singapura, Taiwan, Thailand, Vietnam dan Rusia. Warga Negara Indonesia (WNI) pebisnis APEC dapat mengajukan permohonan untuk memperoleh KPP APEC ke Direktorat Jenderal Imigrasi dengan melampirkan dokumen persyaratan seperti surat rekomendasi dari asosiasi pengusaha dan saldo tabungan minimal Rp. 500.000.000,- (Peraturan Menteri Hukum dan Hak Asasi Manusia Nomor 26 Tahun 2016 pasal 4):

Bagi Warga Negara Asing (WNA) pebisnis APEC, maka pengajuan KPP APEC ditujukan kepada otoritas yang berwenang di negaranya. Pebisnis Australia yang ingin mengajukan KPP APEC ke Indonesia harus mengajukan permohonan ke imigrasi Australia (Department of Home Affairs) selaku otoritas yang berwenang mengeluarkan KPP APEC. Selanjutnya, otoritas negara Australia mengajukan pre clearance ke otoritas negara Indonesia atau negara APEC lainnya. Jika warga 
negara Australia telah memperoleh persetujuan dari Direktorat Jenderal Imigrasi, maka KPP APEC dapat diberikan.

Terdapat dua kemudahan fasilitas keimigrasian yang diperoleh pemegang KPP APEC. Pertama, fasilitas bebas dari pengajuan visa. KPP APEC diberlakukan sebagai Visa kunjungan untuk melakukan perjalanan ke wilayah Indonesia. Bagi WNA Australia pemegang KPP APEC, maka dibebaskan dari kewajiban memiliki visa, dengan masa izin tinggal selama 60 hari. WNI pebisnis APEC juga memperoleh fasilitas kemudahan yang sama jika akan bepergian ke Australia dalam rangka bisnis, diberikan izin tinggal selama 90 hari di Australia. Kedua, kemudahan perlintasan masuk wilayah Indonesia. Pemegang KPP APEC dapat keluar masuk Indonesia melalui Tempat Pemeriksaan Imigrasi (TPI) yang telah ditentukan. Di beberapa TPI tertentu telah disediakan jalur khusus untuk perlintasan pemegang KPP APEC. Daftar TPI tempat perlintasan KPP APEC sebagaimana pada tabel 1 (imigrasi.go.id, 2020)

Tabel 1. Daftar Nama Bandar Udara dan Pelabuhan Laut Tempat Perlintasan KPP APEC

\begin{tabular}{|c|c|c|c|c|}
\hline \multirow[t]{3}{*}{ No. } & \multirow[t]{3}{*}{ Propinsi } & \multicolumn{3}{|c|}{ TPI } \\
\hline & & \multirow{2}{*}{$\begin{array}{l}\text { Jalur Khusus } \\
\text { Bandar Udara }\end{array}$} & \multicolumn{2}{|c|}{ Non-Jalur Khusus } \\
\hline & & & Bandar Udara & Pelabuhan Laut \\
\hline 1. & DKI Jakarta & $\begin{array}{l}\text { Soekarno- } \\
\text { Hatta, Jakarta; }\end{array}$ & $\begin{array}{l}\text { Halim } \\
\text { Perdanakusuma, } \\
\text { Jakarta }\end{array}$ & - \\
\hline \multirow[t]{3}{*}{2} & \multirow[t]{3}{*}{ Kepulauan Riau } & \multirow[t]{3}{*}{$\begin{array}{l}\text { Batam Center, } \\
\text { Batam }\end{array}$} & \multirow[t]{3}{*}{$\begin{array}{l}\text { Hang Nadim, } \\
\text { Batam }\end{array}$} & $\begin{array}{l}\text { Batam, Sekupang, } \\
\text { Batu Ampar, } \\
\text { Nongsa,Marina,Telu } \\
\text { k Senimba. }\end{array}$ \\
\hline & & & & $\begin{array}{l}\text { Tanjung Uban, } \\
\text { Bandar Bintan } \\
\text { Telani, Lagoi, } \\
\text { Bandar Sri Udana } \\
\text { Lobam }\end{array}$ \\
\hline & & & & $\begin{array}{l}\text { Tanjung Pinang Sri } \\
\text { Bintan Pura }\end{array}$ \\
\hline 3 & Bali & $\begin{array}{l}\text { Ngurah Rai, } \\
\text { Denpasar }\end{array}$ & - & - \\
\hline 4 & Sumatera Utara & $\begin{array}{l}\text { Kualanamu, } \\
\text { Medan }\end{array}$ & - & Belawan, Medan \\
\hline 5 & Jawa Timur & $\begin{array}{l}\text { Juanda, } \\
\text { Surabaya }\end{array}$ & - & - \\
\hline
\end{tabular}




\begin{tabular}{|c|l|c|l|c|}
\hline 6 & Riau & - & $\begin{array}{l}\text { Sultan Syarif } \\
\text { Kasim II, } \\
\text { Pekanbaru }\end{array}$ & $\begin{array}{l}\text { Dumai } \\
\text { Yos Sudarso }\end{array}$ \\
\hline 7 & Sumatera Barat & - & $\begin{array}{l}\text { Minangkabau, } \\
\text { Padang }\end{array}$ & - \\
\hline 8 & Yogyakarta & - & $\begin{array}{l}\text { Adi Sucipto, } \\
\text { Yogyakarta }\end{array}$ & - \\
\hline 9 & NTB & - & $\begin{array}{l}\text { Selaparang, } \\
\text { Mataram }\end{array}$ & - \\
\hline 10 & $\begin{array}{l}\text { Kalimantan } \\
\text { Timur }\end{array}$ & - & $\begin{array}{l}\text { Sepinggan, } \\
\text { Balikpapan }\end{array}$ & - \\
\hline 11 & $\begin{array}{l}\text { Sulawesi } \\
\text { Selatan }\end{array}$ & - & $\begin{array}{l}\text { Hasanuddin, } \\
\text { Makasar }\end{array}$ & - \\
\hline 12 & Sulawesi Utara & - & $\begin{array}{l}\text { Sam Ratulangi, } \\
\text { Manado }\end{array}$ & - \\
\hline 13 & NTT & - & $\begin{array}{l}\text { El Tari, } \\
\text { Kupang } \\
\text { Adi } \\
\text { Sumarmo, } \\
\text { Surakarta }\end{array}$ & - \\
\hline 14 & Surakarta & - & $\begin{array}{l}\text { Ahmad Yani, } \\
\text { Semarang; }\end{array}$ & - \\
\hline 15 & Jawa Tengah & - & $\begin{array}{l}\text { Husein } \\
\text { Sastranegara, } \\
\text { Bandung }\end{array}$ & - \\
\hline 16 & Jawa Barat & - & & - \\
\hline
\end{tabular}

Sumber: www.imigrasi.go.id (2020)

WNI yang akan keluar masuk wilayah Australia juga diberikan fasilitas yang sama yakni dapat keluar masuk Australia melalui Bandara Adelaide, Brisbane, Cairns, Darwin, Sydney, Melbourne dan Perth (imigrasi.go.id, 2020).

\section{b. Working Holiday Visa}

Fasilitas keimigrasian lain yang dapat digunakan dalam skema Kerjasama IA-CEPA adalah Working Holiday Visa/Visa Sambil Bekerja (WHV). WHV merupakan kerjasama bilateral yang dimulai sejak tahun 2009. Skema ini bertujuan untuk mendorong pertukaran budaya dan meningkatkan hubungan orang perorangan (people-to-people) antar kedua negara. Melalui WHV, warga negara kedua negara dapat berlibur sekaligus bekerja dengan ketentuan berlibur sebagai tujuan utama, bekerja bersifat insidental.

Skema WHV merupakan salah satu jenis visa tinggal terbatas dengan indeks visa C320, kemudahan bekerja sambil berlibur (Peraturan Menteri Hukum dan HAM Nomor 51 Tahun 2016). WHV hanya diperuntukkan untuk orang-orang 
yang mempunyai kualifikasi tertentu seperti pendidikan tersier. Pemohon minimal harus memiliki pendidikan Diploma Tiga/D3. Persyaratan lainnya yaitu berusia 18 hingga 30 tahun (Kedutaan Besar Australia Indonesia, 2020). Bagi pemohon WHV warga negara Australia dapat mengajukan permohonan WHV kepada Perwakilan Republik Indonesia di Australia. Ketentuan jangka waktu tinggal WHV bagi warga negara Australia adalah sebagai berikut:

a.Untuk berlibur sambil bekerja paling lama enam bulan

b.Belajar atau mengikuti pelatihan paling lama empat bulan.

(Konsulat Jenderal RI Melbourne-Victoria, 2020)

Berdasarkan Peraturan Menteri Hukum dan HAM Nomor 24 Tahun 2016 tentang Prosedur Teknis Permohonan dan Pemberian Visa Kunjungan dan Visa Tinggal Terbatas Pasal 39, persyaratan untuk memperoleh visa WHV (indeks visa C320) bagi Warga Negara Australia adalah sebagai berikut:

a. Surat penjamin;

b. Surat rekomendasi dari instansi keimigrasian di negara asal;

c. Sertifikat Pendidikan dari perguruan tinggi atau Lembaga Pendidikan yang setara dengan bagi yang sudah lulus atau surat keterangan sebagai mahasiswa aktif paling singkat dua tahun dari perguruan tinggi di negara yang bersangkutan.

d. Tiket perjalanan pergi dan pulang atau bukti kepemilikan uang yang senilai dengan harga tiket tersebut;

e. Paspor kebangsaan yang sah dan masih berlaku paling singkat 18 (delapan belas) bulan;

f. Bukti biaya hidup paling sedikit lima ribu dollar Australia.

g. Pas foto berwarna latar belakang putih $4 \times 6 \mathrm{~cm}$ sebanyak dua lembar.

Persyaratan yang sama juga berlaku bagi pemuda Indonesia yang ingin mengajukan WHV ke Australia. Permohonan WHV diajukan ke Kedutaan Besar Australia. Namun terdapat satu persyaratan tambahan bagi WNI yaitu surat rekomendasi dari Direktorat Jenderal Imigrasi. Di Australia, WHV merupakan subclass visa 417 (Australian Government, Department of Home Affairs, 2020). Ketentuan jangka waktu WHV bagi WNI adalah sebagai berikut: 
a. tinggal selama maksimal 12 bulan di Australia dengan tujuan wisata (holiday) dan dapat bekerja;

b. tanpa harus melalui mekanisme sponsorship;

c. dapat bekerja (termasuk magang) di beberapa employer dengan jangka waktu maksimal 6 bulan;

d. dapat digunakan untuk kegiatan pelatihan (training) atau short-course dengan maksimal waktu 4 bulan.

Pada awal kerjasama, skema WHV memberikan 100 kuota visa/tahun. Sejak tahun 2013 hingga 2020, kuota ditambah menjadi 1000 kuota per tahun. Meskipun skema kerjasama WHV pada awalnya dibuat bukan dalam kerangka Kerjasama IA-CEPA, namun kedua negara telah sepakat bahwa WHV telah menjadi salah satu fasilitas keimigrasian dalam kerangka IA-CEPA. Hal ini dinyatakan oleh pemerintah Australia bahwa melalui perjanjian IA-CEPA, kerjasama WHV akan tetap dilanjutkan dan kuota bagi pemuda Indonesia akan ditingkatkan dari 1000 kuota per tahun menjadi 5000 per tahun (Minister for Trade, Tourism and Investment, 2020)

\section{Peran Imigrasi Sebagai Fasilitator pembangunan masyarakat Dalam Kerangka Kerjasama IA-CEPA}

Fungsi keimigrasian adalah bagian dari urusan pemerintahan negara dalam memberikan pelayanan Keimigrasian, penegakan hukum, keamanan negara, dan fasilitator pembangunan kesejahteraan masyarakat (Undang-undang Keimigrasian, 2011). Adanya kebijakan kemudahan keimigrasian dalam bentuk pemberian KPP APEC dan WHV oleh imigrasi bukan hanya merupakan fungsi pelayanan namun juga merupakan fungsi pembangunan kesejahteraan masyarakat. Hal ini berarti Direktorat Jenderal Imigrasi telah menjalankan fungsinya secara aktif sebagai fasilitator pembangunan masyarakat dengan memberikan kebijakan yang mendukung perpindahan modal manusia (transfer of human capital). Fasilitas keimigrasian yang diberikan merupakan salah satu kunci terlaksananya partnership dengan baik yang pada akhirnya akan mendorong pertumbuhan ekonomi. Selain itu, imigrasi tidak hanya memfasilitasi pembangunan kesejahteraan masyarakat, namun juga dapat meningkatkan hubungan people to people antara kedua negara. 
Terlebih lagi, mengingat hubungan kedua negara yang selalu diwarnai ketidakpercayaan.

IA-CEPA dapat dimanfaatkan sebagai momentum peningkatan kerjasama keimigrasian di masa yang akan datang, terutama bagi Indonesia. Sebagaimana Indonesia telah berhasil meningkatkan kuota WHV ke Australia dari 1000 kuota menjadi 5000 kuota per tahun, maka terdapat prospek kerjasama di bidang lalu lintas manusia yang dapat menjadi agenda di masa yang akan datang. Misalnya penjajakan kemungkinan pemberian Bebas Visa Kunjungan (BVK) dan Visa Kunjungan Saat Kedatanagan (VKSK) bagi WNI yang hendak ke Australia. Beberapa hal yang dapat dijadikan dasar pertimbangan realisasi kerjasama tersebut yaitu bahwa Indonesia telah memberikan fasilitas BVK dan VKSK bagi Australia terlebih dahulu, serta jumlah wisatawan Indonesia yang cukup tinggi ke Australia. Menurut bisnis.com, pertumbuhan wisatawan Indonesia yang berkunjung ke Australia terus meningkat selama beberapa tahun terakhir. Pada tahun 2017, tercatat lebih dari 193.000 wisatawan Indonesia yang datang ke Australia, meningkat sekitar 7,2\% dibandingkan tahun 2016. Lebih lanjut, Australia menargetkan jumlah kunjungan wisatawan asal Indonesia meningkat $10 \%$ per tahun. Australia menargetkan jumlah turis Indonesia mencapai 220.000 orang pada 2018 (Mudassir, 2020). Namun demikian, keberhasilan agenda tersebut dipengaruhi beberapa faktor, salah satunya situasi politik antar kedua negara. Disinilah pentingnya diplomasi dari pemerintah Indonesia untuk dapat merealisasikan agenda tersebut. Pemberian fasilitas keimigrasian BVK dan VKSK dari pemerintah Australia kepada Indonesia dapat menjadi prospek riset di masa yang akan datang mengingat limitasi dari ruang lingkup penulisan kali ini tidak memungkinkan untuk melakukan penelitian tentang BVK dan VKSK secara mendalam.

\section{Kesimpulan}

Direktorat Jenderal Imigrasi telah menjalankan fungsinya sebagai fasilitator pembangunan masyarakat dalam kerangka IA-CEPA. Hal ini diimplementasikan melalui dua kebijakan keimigrasian yaitu KPP APEC dan WHV. Kedua kebijakan tersebut dikeluarkan sebelum IA-CEPA disepakati, namun dapat terus digunakan 
selama belum ada kebijakan keimigrasian yang khusus dikeluarkan dalam kerangka IA-CEPA. Kebijakan KPP APEC memberikan kemudahan bagi pebisnis WNA Australia maupun WNI yang akan masuk keluar wilayah Indonesia-Australia dalam rangka kunjungan bisnis. Kebijakan ini memberikan kemudahan yaitu sebagai izin khusus yang berlaku selama lima tahun untuk keluar masuk wilayah Indonesia atau Australia. KPP APEC juga memberikan kemudahan dalam hal adanya jalur khusus perlintasan di bandar udara atau pelabuhan laut. Sementara itu, kebijakan WHV memberikan kemudahan dalam hal perlintasan dan hubungan people to people antara kedua negara.

Mengingat pentingnya partnership IA-CEPA bagi Indonesia, terutama dalam hal peningkatan investasi, maka dapat dilakukan kajian untuk lebih memperbanyak TPI di wilayah yang akan menjadi tujuan investasi Australia di Indonesia. Dengan demikian, pebisnis dan tenaga ahli Australia dapat lebih mudah masuk ke luar wilayah Indonesia. Di dalam penelitian ini, terdapat kendala tidak tersedianya data KPP APEC yang dikeluarkan oleh Direktorat Jenderal Imigrasi. Oleh karenanya, diharapkan Direktorat Jenderal Imigrasi dapat mempublikasikan statistik penerbitan KPP APEC dan WHV di website sebagai bagian dari publikasi kepada masyarakat. Adanya publikasi statistik bermanfaat bagi penelitian dalam rangka evaluasi kebijakan dan menganalisis sejauh mana kebijakan keimigrasian dapat memfasilitasi pertumbuhan ekonomi.

\section{Referensi}

Andriani, Y.\&Andre. (2017). Implikasi Perjanjian Kemitraan Ekonomi Komprehensif Indonesia-Australia (IA-CEPA) terhadap Perdagangan Luar Negeri Indonesia. Andalas Journal of International Studies 6, no.1, (2017): 79-92, http://ajis.fisip.unand.ac.id/index.php/ajis/article/view/70/63

Anggito, A., \& Setiawan, J. (2018). Metodologi penelitian kualitatif. CV Jejak (Jejak Publisher).

Australian Government Department of Foreign Affairs and Trade (2020). Indonesia-Australia Comprehensive Economic, diakses 15 April 2020 
pada https://www.dfat.gov.au/trade/agreements/not-yet-inforce/iacepa/Pages/indonesia-australia-comprehensive-economicpartnership-agreement

Australian Government, Department of Foreign Affairs and Trade (2020). Why Has the Australian Government Negotiated a Comprehensive Economic Partnership Agreement with Indonesia?, diakses 4 April 2020 pada https://www.dfat.gov.au/trade/agreements/not-yet-inforce/iacepa/Pages/why-has-the-australian-government-negotiated-acomprehensive-economic-partnership-agreement-with-indonesia

Australian Government, Department of Home Affairs. (2020). First Working Holiday Visa, diakses 28 April 2020 pada https://immi.homeaffairs.gov.au/visas/getting-a-visa/visa-listing/workholiday-417/first-working-holiday-417

Bakry, U.S. (2017). Dasar-dasar Hubungan Internasional, Jakarta: Prenadamedia Group

CNN Indonesia. (2020). Sepakati IA-CEPA, Jokowi ingin optimalkan Investasi Australia, diakses $\quad 1 \quad$ April $2020 \quad$ pada https://www.cnnindonesia.com/ekonomi/20200209192156-92473073/sepakati-ia-cepa-jokowi-ingin-optimalkan-investasi-australia Direktorat Jenderal Imigrasi. (2020). APEC Business Travel Card (ABTC). diakses 1 April 2020 pada https://www.imigrasi.go.id/info/abtc

Indonesia-Australia Comprehensive Economic Agreement Chapter 12 Movement of Natural Persons .(2020). article 12.5 diakses 4 April 2020 pada https://www.dfat.gov.au/sites/default/files/iacepa-chapter-12movement-of-natural-persons.pdf

Kedutaan besar Australia Indonesia. (2020). Mengajukan visa Bekerja dan Berlibur (Work and Holiday Visa) ke Australia", diakses 27 April 2020 pada https://indonesia.embassy.gov.au/jaktindonesian/Checklist_WHol.htm 1 
Kedutaan Besar Australia Indonesia, (2020). Berbisnis dengan Australia, diakses 29 April 2020 pada https://indonesia.embassy.gov.au/jaktindonesian/trade.html Konsulat Jenderal RI Melbourne-Victoria, Australia. (2020). Ratifikasi IndonesiaAustralia IA-CEPA akan Dorong Kerjasama Ekonomi Antara Indonesia dan Australia, 08 Februari 2020, diakses 10 April 2020 pada https://kemlu.go.id/melbourne/id/news/4701/ratifikasi-indonesiaaustralia-comprehensive-economic-partnership-agreement-ia-cepaakan-dorong-kerja-sama-ekonomi-antara-indonesia-dan-australia

Konsulat Jenderal RI Melbourne-Victoria, Australia. (2020). Working Holiday Visa, diakses $27 \quad$ April $2020 \quad$ pada https://kemlu.go.id/melbourne/en/pages/working_holiday_visa/1140/e tc-menu

Kumparan.com. (2020). Presiden Jokowi sebut Monash Univeristy akan dibangun di Indonesia, diakses 30 April 2020 pada https://kumparan.com/kumparannews/presiden-jokowi-sebut-monashuniversity-akan-dibangun-di-indonesia-1 soMNFzgPSm/full

Maharani, T. (2020). DPR Sahkan Kerja Sama Ekonomi Indonesia dan Australia IA-CEPA, diakses 1 April 2020 pada https://nasional.kompas.com/read/2020/02/06/18572231/dpr-sahkankerja-sama ekonomi-indonesia-dan-australia-ia-cepa

Minister for Trade, Tourism and Investment. (2019). Remarks At IndonesiaAustralia Comprehensive Economic Partnership Agreement (IACEPA) Signing Ceremony, 4 Maret 2019, diakses 5 April 2020 pada https://www.trademinister.gov.au/minister/simonbirmingham/speech/remarks-indonesia-australia-comprehensiveeconomic-partnership-agreement-ia-cepa-signing-ceremony

Mudassir, R. (2018). Australia Sasar 220.000 Wisatawan Indonesia, diakses 29 April 2020" pada https://ekonomi.bisnis.com/read/2018 0309/12/747951/australia-sasar-220.000-wisatawan-indonesia 
Peraturan Menteri Hukum dan HAM Nomor 26 Tahun 2016 tentang Kartu Perjalanan Pebisnis Asia Pacific Economic Cooperation, Tanggal 30 Juni 2016

Peraturan Menteri Hukum dan HAM Nomor 51 Tahun 2016 tentang Perubahan atas

Peraturan Menteri Hukum dan HAM Nomor 24 Tahun 2016 tentang Prosedur Teknis Permohonan dan Pemberian Visa Kunjungan dan Visa Tinggal Terbatas, Tanggal 15 Desember 2016

Riyandi, S. (2017). Kontribusi RI dalam Global Value Chain masih kalah dari Malaysia, 19 November 2017, diakses 29 April 2020 pada https://www.merdeka.com/uang/kontribusi-ri-dalam-global-valuechain-masih-kalah-dari-malaysia.html

Sebayang, R.I.B. (2019). IA-CEPA Resmi Diteken, Dua Kampus Australia ini Siap Masuk RI, diakses 30 April pada 2020https://www.cnbcindonesia.com/news/20190304191215-458828/ia-cepa-resmi-diteken-dua-kampus-australia-ini-siap-masuk-ri Souisa, H.(2020). Banyak Negara Berburu Kelinci': COVID-19 Ubah Perilaku Hubungan Internasional, diakses 28 April 2020 pada https://www.abc.net.au/indonesian/2020-04-23/hubunganinternasional-setelah-covid-19:-akankah-berubah/12175106

Sulistiyanto, P. (2010). Indonesia-Australia Relations in the Era of Democracy: The View from the Indonesian Side, Australian Journal of Political Science 45, no.1 (2010): 117-132

Tickner, J. A. (2001). Gendering World Politics: Issues and Approaches in the Post Cold War Era, New York: Columbia University Press

Troath, S. (2020). Australia-Indonesia: Building Trust, diakses 5 April 2020 pada https://www.lowyinstitute.org/the-interpreter/australia-indonesiabuilding-trust

Undang-undang Nomor 6 Tahun 2011 tentang Keimigrasian, Tanggal 5 Mei 2011 Wilson, J. D. (2016). The changing architecture of the Asia-Pacific trading system: Implications for the Indonesia-Australia Comprehensive Economic Partnership Agreement (IA-CEPA), Briefing paper for the Australia- 
Indonesia Business Partnership Group (IA-BPG), The University of Western Australia

Workman, D. (2020). Australia's Top Trading Partners, diakses 27 April 2020 pada http://www.worldstopexports.com/australias-top-import-partners/ 